\title{
Special Issue on Fire Safety of High-Rise Buildings
}

\author{
Longhua Hu*, State Key Laboratory of Fire Science, University of Science and \\ Technology of China, Hefei, Anhui, China \\ James A. Milke, Department of Fire Protection Engineering, University of \\ Maryland, College Park, MD, USA \\ Bart Merci, Department of Flow, Heat and Combustion Mechanics, Ghent \\ University-UGent, Ghent, Belgium
}

Fire safety of high-rise buildings has attracted extensive attention in past decades. There are more serious high-rise building fire accidents resulting in catastrophic loss of human lives and properties occurred frequently in recent years, such as the collapse of the World Trade Center (WTC) towers in 2001, the CCTV/TVCC Tower Building Fire in 2009 etc. Compared to normal compartment fires, the fire behavior in high-rise buildings has some special features, including: (1) the extensive use of external facade insulation materials bringing new fire safety issues; (2) specific fire evolution and smoke transport due to complex building structures; (3) structural safety of high-rise buildings during and after a fire hazard; (4) human evacuation.

In order to meet the above requirements, plenty of relevant research studies have been carried out and more and more building codes, such as NFPA101 in the U.S. (NFPA 2012), have incorporated changes to reflect the research advances. The Special Issue on fire safety of high-rise buildings of Fire Technology is devoted to both fundamental and applied research and includes experimental, theoretical, as well as computational investigations, that contribute towards the understanding and improvement of fire safety in high-rise buildings, including: (1) flammability of highrise building materials; (2) ignition, spread and fire growth; (3) smoke transport and control; (4) structural response; and (5) human evacuation.

In recent years, highly advanced production techniques have been developed in the building external facade material industry [1]. Exterior walls made of organic insulation materials, such as polystyrene and polyurethane, are widely used in high-rise buildings due to the demands for energy savings. However, flames can spread very quickly over their surface and produce large amounts of toxic products once these combustible insulation materials are ignited. Hence fire safety issues of external facade insulation materials have become a major issue for highrise buildings. This leads directly to a discussion about the fire performance of External Thermal Insulation Composite System (ETICS), discussed by Hajduković

\footnotetext{
* Correspondence should be addressed to: Longhua Hu, E-mail: hlh@ustc.edu.cn
} 
et al. [2]. Many countries offer series of methods to meet the requirements of the fire resistance of high-rise buildings. Hopkin provides a review of fire resistance expectations for High-Rise Apartment Buildings in the UK [3].

Complex building structures could also lead to specific fire evolution behavior. The existence of a stairwell, elevator shaft, tube well or other special structure in the high-rise building could cause a stack effect and piston effect during the fire. This will contribute significantly to the spread of fire and smoke transport processes and the study of smoke movement in shafts and its associated risks on building occupants becomes more important [4-6]. Smoke transport and control is a critical area of fire research especially for high-rise buildings, to which several papers in the Special Issue are devoted: Acikyol et al. [7] investigate the effect of the presence of a non-pressurized vestibule (fire protection lobby, FPL) before entering the stair at each floor; Qi et al. [8] introduce a method to calculate temperature distribution and its associated neutral plane level (NPL) location - an important factor for the evaluation of risk of smoke spread in high-rise buildings - based on a coupled model of smoke temperature profile, flow rate and pressure distribution inside a shaft; and Strege et al. [9] take differential pressure measurements in 15 high-rise buildings in four different cities (Cleveland, Baltimore, Minneapolis, and Philadelphia) to characterize the magnitude of stack effect within stairwells and elevator shafts.

Another aspect is the possible rupture of glass in the context of curtain walls. The fire can emerge from the broken window and will not be easily controlled. Consequently, the fire resistance of glass as a structural element, has drawn more and more attention due to increasing use of glass curtain walls. Chen et al. [10] carried out a series of experiments on float glass in an enclosed compartment under radiant heat to investigate the effect of shaded width on the breaking behavior of window glass.

Fire also brings threats to the structures of high-rise buildings. Major structures such as glass curtain walls and steel structures lead to very complex mechanical load distribution. The key components and nodes in the structure system are likely to fail or may even lead to the collapse of the entire building due to nonuniform heat fluxes in a fire. Once this happens, a secondary disaster could occur. Consequently, the structural safety of high-rise buildings has also attracted great attention in the research field. In this Special Issue Xiao et al. [11] report results from fire tests and low-frequency cyclic loading tests after fire on 3 conventional high strength concrete (HSC) shear walls and a superimposed HSC shear wall with precast recycled aggregate concrete (RAC) panels. Lu et al. [12] describe the use of a high-performance finite element model to simulate the mechanical behavior of reinforced concrete (RC) members in fire-induced progressive collapse.

Finally, human evacuation in high-rise buildings in case of fire also becomes a major safety issue because personnel evacuation behavior in high-rise buildings shows complex multi-directional characteristics and equipment like interphones may have trouble in signal transmission when used at the fire scene. Hence a series of problems need to be solved for human evacuation in case of high-rise building fires. To study how evacuees behave and what factors influence their behavior during evacuation, Ding et al. [13] carry out extensive experiments with respect to the use of elevators. Li et al. [14] suggest that a frequency-dependent assessment 
should be considered for investigating the reliability of the wireless communication system in case of fire in high-rise buildings.

The papers mentioned above demonstrate the wide range of topics important to both fundamental and applied research on fire science and fire safety engineering for high-rise buildings. We are grateful to all contributors to this Special Issue for their hard work and creative ideas, leading to a step forward in making high-rise buildings more fire safe.

\section{References}

1. Tu KM, Quintiere JG (1991) Wall flame heights with external radiation. Fire Technol 27:195-203

2. Hajduković M, Knez N, Knez F, Kolšek J (2016) Fire performance of external thermal insulation composite system (ETICS) facades with expanded polystyrene (EPS) insulation and thin rendering. Fire Technol. doi:10.1007/s10694-016-0622-2

3. Hopkin D (2016) A review of fire resistance expectations for high-rise UK apartment buildings. Fire Technol. doi:10.1007/s10694-016-0571-9

4. Lie TT, McGuire JH (1975) Control of smoke in high-rise buildings. Fire Technol 11:5-14

5. Hadjisophocleous G, Jia Q (2009) Comparison of FDS prediction of smoke movement in a 10-storey building with experimental data. Fire Technol 45:163-177

6. Wang Y, Zalok E, Hadjisophocleous G (2011) An experimental study of smoke movement in multi-storey buildings. Fire Technol 47:1141-1169

7. Acikyol BH, Balik G, Kilic A (2015) Experimental investigation of the effect of fire protection lobby on stair pressurization system in a high-rise building. Fire Technol. doi:10.1007/s10694-015-0560-4

8. Qi D, Wang L, Zmeureanu R (2015) The effects of non-uniform temperature distribution on neutral plane level in non-adiabatic high-rise shafts during fires. Fire Technol. doi:10.1007/s10694-015-0554-2

9. Strege S, Ferreira M (2016) Characterization of stack effect in high-rise buildings under winter conditions, including the impact of stairwell pressurization. Fire Technol. doi:10.1007/s10694-016-0562-X

10. Chen H, Wang Q, Wang Y, Zhao H, Sun J, He L (2016) Experimental and numerical study of window glass breakage with varying shaded widths under thermal loading. Fire Technol. doi:10.1007/s10694-016-0596-0

11. Xiao J, Xie Q, Li Z, Wang W (2016) Fire resistance and post-fire seismic behavior of high strength concrete shear walls. Fire Technol. doi:10.1007/s10694-016-0582-6

12. Lu X, Li Y, Guan H, Ying M (2016) Progressive collapse analysis of a typical supertall reinforced concrete frame-core tube building exposed to extreme fires. Fire Technol. doi:10.1007/s10694-016-0566-6

13. Ding N, Chen T, Zhang H (2016) Experimental study of elevator loading and unloading time during evacuation in high-rise buildings. Fire Technol. doi:10.1007/s10694-0160597-Z

14. Li Y, Yuan H, Lu Y, Xu R, Fu M, Yuan M, Han L (2016) Experimental studies of electromagnetic wave attenuation by flame and smoke in structure fire. Fire Technol. doi:10.1007/s10694-016-0608-0 